\title{
The Combination of Natural Elements and Characteristic of Javanese Women in the Lexicon of the Traditional Household Equipment
}

\author{
M. Suryadi ${ }^{1 *}$, Riris Tiani ${ }^{1}$, and Hana Faza Surya Rusyda ${ }^{2}$ \\ ${ }^{1}$ Department of Indonesian Literature, Faculty of Humanities, Diponegoro University, Semarang- \\ Indonesia \\ ${ }^{2}$ Department of Interior Design, School of Creative Industries, Telkom University, Bandung- \\ Indonesia
}

\begin{abstract}
This study aims to describe the combination of non-metallic natural elements found in traditional household appliances on the character of Javanese women attached to the lexicon of traditional household appliances. The relationship between natural elements and traditional household appliances is adhered to when the equipment is made and the functions of the appliance. This combination holds the values of Javanese philosophy. This research uses observation and in-depth interviews which are reinforced by data triangulation. This research also uses a matched method (metode padan) as the analytical method which matches the combination of natural elements with the referential value contained in the lexicon of the traditional household equipment. The findings in this study are the natural elements used as the basis for making traditional household appliances chosen by considering three elements, namely religious elements, natural ecosystem elements, and health elements. These three elements are attached to three semantic components: word-conceptreference, which is used during the process of naming the identity of the lexicon of the traditional household equipment.
\end{abstract}

Keywords: natural, Javanese women character, traditional kitchen.

\section{Introduction}

The strength of Javanese culture lies in all sides of life and all life behaviors. The side of life that stands out in harmony with nature. Nature is a part of human life that needs to be maintained and maintained in balance so that the needs of air, water, and land are the priority [1]. The most closely related phrases in Javanese advice are banyu kuwi sejatining urip, angin kuwi nyegerke urip, lan lemah kanggo ngadeke urip 'water is the source of life,

\footnotetext{
* Corresponding autor : mssuryadi07@gmail.com
} 
the air refreshes life, and the land is to uphold life'. The expression reflects that water, wind, and land are an inseparable unity. Behavior is the order of human life that has been arranged in a social order in the form of social regulation. This social regulation is an unwritten regulation or obligation which is always obeyed by Javanese people [2]. This regulation is strictly obeyed to maintain harmony with the universe. Javanese expressions that reflect compliance with social regulation are bicike wong Jawa kuwi iso didelok seko tindak tandukke, tindakke becik uripe tentrem tanpolah 'the virtue of the Javanese can be seen from their behavior, if their behavior is true and honest then their life will be peaceful without any disturbance'.

Conservation and utilization of nature are highly ordered in Javanese life [3]. Every aspect of Javanese life is always full of calculations, both in determining the quality of natural materials to the time of cutting natural materials [4]. Thus, the protection and preservation of nature will be maintained by the Javanese. This evidence can be seen in the quality of materials used in Javanese life, for example, traditional kitchen equipment. The use of natural elements such as bamboo and coconut trees as the basic material for making traditional household appliances is already calculated at the time of logging.

Traditional household appliances cannot be separated from the side of Javanese women's lives [5]. Javanese women have a significant share in regulating the economy in the sector of food needs and sufficiency on a micro family scale. The life of a Javanese family is reflected in the comfort of a household. One of the parameters of Javanese family comfort lies in the strength of food, namely the strength of kitchen needs. Thus, the kitchen needs are portrayed from the skillful role of Javanese women. Thus, it is no exaggeration when traditional kitchen or household appliances are attached to the character of Javanese women [6]. Javanese expressions that reflect harmony with the character of Javanese women are genggemane kuat, rembugane alus, lan tindaktanduke ngelaraske ati. Javanese women have power in household dipper arrangements.

Internal arrangements in all Javanese household life are in the hands of Javanese women. A successful family cannot be separated from the strength of the female figure, namely the wife. The success of children also cannot be separated from the role of women, namely the figure of the mother. Thus, the role of Javanese women is as a director of success in the household. The character of Javanese women is a milestone of household success in Javanese life and culture. All of these characters are portrayed in all traditional household appliances. In general, traditional household utensils are made from natural elements owned by the land of Java.

\section{Literature Review}

Research on the combination of natural elements as a basic material for making traditional household appliances that reflects the character of Javanese women is not very popular. The low level of interest in this area is due to changes in the orientation of people to technological advancements and modernization of tools. It is not realized that the use of tools made from nature has extraordinary properties. These properties include, in the health sector, that natural materials do not contain heavy metals thus it is safe for human health. In the field of creativity, natural materials will teach discipline and perseverance in life.

Excellence that reflects the balance between humans and nature is a reference priority in this study in addition to the results of other studies related to the character of women and philosophy in Javanese culture. Some scientific works that are referred to sharpen the analysis, among others, as follows.

Human life cannot be separated from the balance of nature. Nature is the most important part to meet human needs, both as a source of life and as a place to live. The role of humans is very important whether it can determine the preservation of nature or even be damaged 
[7]. Javanese people are very obedient to the balance of nature and the environment, especially in the pattern of planting and harvesting land, all calculated in detail [8].

The strength of the character of Javanese women as the front liner in the family is often ignored, even deliberately built in the concept of Javanese thinking that Javanese women are seated as kanca winking or 'domestic forces' in the household. The concept of domestic power does not always mean negative. Very high philosophical values, even a great family, a great husband, and a strong child built and directed by a formidable wife [9].

The power of non-metallic nature is firmly embedded in the order of the Javanese community, especially those which are livelihood-oriented on rice fields and plantations. The culture embedded in Javanese society in harmony with nature. This culture then produces a lot of philosophical values ${ }^{1213}$, natural balance, and also the maintenance of the need for water sources in rural areas that are free from scouring of property [10].

\section{Research Methodology}

This type of research is a qualitative descriptive study that emphasizes the strength and validity of the data. The research location chosen was Kudus regency. Data collection methods used in this study were observation and in-depth interviews. The chosen observation is to participate directly so that the selected informants can be relied on to obtain the data needed in the study. The in-depth interview method is carried out to obtain all the data information directly. This method is also equipped with research instruments in the form of a Question List. The questionnaire is open, with the hope that additional information will not be written in the questionnaire. The data obtained will be triangulated and data truth and validity will be obtained. The data that has been obtained will be classified by the data tabulation system, which is sorted based on the analysis system.

The data analysis method used is to parse the lexicon component in household appliances based on the form (word), concept (philosophy), and reference to the links between the elements (the analogy of the triangle of the meaning). The results of the first phase of the analysis will be linked to the elements of nature and the character of women embedded in Javanese culture. Thus, the data are analyzed by utilizing five vertices namely form-concepts-reference-elements of nature-character. This five-knot theory is a novelty of the theory that was developed by its beginners namely Sapir and Whorf [11] and OdgenRichard [12].

\section{The Combination of Nature and Character of Javanese Women in the Lexicon of the Traditional Household}

Local wisdom in Javanese society is very rich. This richness is stored on every side of Javanese life. The life of the Javanese people is always regulated by social arrangements in the form of customs or traditions as well as legal rules agreed upon by all residents or members of their society. Local wisdom stored in tradition includes making traditional household appliances. This work is inherited based on hereditary inheritance.

Inheritance is taught naturally, through the process of imitating deeds and work habits, which are accompanied by a perseverance at work. This natural process instills noble behavior that is, a culture of queuing, patient, obedient, and respecting elders. Knowledge gained from the experience of working for his ancestors. In Javanese culture, many jobs are inherited based on their genetics, for example, blacksmiths, pottery craftsmen, weaving craftsmen, and craftsmen making traditional household appliances. As a result of inheritance, sometimes the name of the job is attached to the maker. 


\subsection{Natural Elements in Traditional Home Appliances}

Traditional household equipment in Javanese society is the main tool in household life. Evidence that shows that household equipment is used as the main tool can be shown when marrying Javanese women, one of the expensive equipment is household appliances, for example, dhandang 'tools for cooking rice', cauldrons 'tools for cooking vegetables', siwur 'tools for taking water or a dipper'.

This research focuses more on household appliances made of non-metallic materials, which are made of bamboo. This plant material was chosen because it has a high philosophical value and is friendly to human health.

Traditional household appliances made from natural materials are often found in traditional tools. Bamboo is an option for Javanese people, on the basis that bamboo trees are often found on the island of Java, with various types, for example, Petung bamboo, Apus bamboo, Javanese bamboo, and yellow bamboo. The most chosen material is Petung bamboo because of the high-quality and long durability.

Traditional household utensils made from bamboo, namely tampah (winnowing pan), besek (bucket), keranjang (basket), dunak (basket), and wakul (a kitchen utensil for cooked rice). Each piece of equipment has its bamboo segment. Besek is made from a mediumaged bamboo-segment whose meat and bamboo skin are utilized so that it is easy to form and is not easily broken. Keranjang and dunak use medium-aged bamboo skin to be easily woven and not easily broken. Wakul specifically utilizes old bamboo skin. Old bamboo skins can add fragrance to rice and become fluffier.

\subsection{Character of Javanese Women in Javanese Culture}

Javanese women have unique strengths in the order of Javanese society. The uniqueness lies in the sector to maintain household survival. The front sector has diplomatic power. The central sector has the power to balance the household. The back sector has the power to maintain the family economy.

In the front sector, Javanese women have a character that reflects flexible and gentle behavior, which also reflects the ability to maintain ethics, be polite in speaking, solve problems by avoiding conflict. This character is suitable as a diplomat character. The character of the diplomat is reflected in Javanese expressions, as follows. Pusaka ingkang paling sekti niku mboten tumbak lan keris, naming ingkang temen sektinipun inggih punika lati lan jati diri. Lelati becik agawe santoso lan agawe rukune bebrayan, iku kabeh neng trahe tiyang estri. Broadly speaking, this Javanese expression can be interpreted as a portrait that the character of Javanese women is as an ambassador of harmony and harmony in internal and external in a household. Likewise, with polite speech, all can be resolved without causing conflict. Along with these expressions, there are also other expressions, namely, atos aja diwales atos, sengak aja diwales sengak naming walesa kara ngemong lan pangkuna, kowe bakal menang sing saksejatinine menang. This phrase illustrates that the character adheres to the figure of Javanese women, that actions that are not pleasant should not be responded to by actions that are not pleasant either but respond with commendable actions to obtain a true victory.

Javanese culture is very noble in describing the characterization of Javanese women, both behavioral and physical disposition. Physically, Javanese women are described as follows, as a padmini figure, a citrini figure, a sankini figure, and a hastini figure. Padmini figure as a portrait of a woman with perfect physical beauty. Citrini figure as an description of a beautiful and artful woman. Sankini figure is a symbol of a woman with a tall, thin physical posture. Hastini figure is a portrait of Javanese women who are short, fat and like to eat. 


\subsection{The Philosophical Value of Javanese Women in the Lexicon of the Traditional Household Equipment}

The philosophical values inherent in Javanese women, both originating from Javanese literature and history as well as those stored in written or oral traditions, as legends, fables, or solace. This study focuses more on the philosophical values inherent in the portrait of traditional household appliances. The most common source of information found aside from legends, Javanese expressions are through lexicon reconstruction and semantic construction.

The lexicon of traditional household appliances which holds the philosophical values of Javanese women's characters often shows the uniqueness of the physical shape of the female body and also has a fundamental function in the order of Javanese life. The unique lexicon is the tampah (winnowing pan) or 'tool to separate rice'.

The lexicon of the tampah (winnowing pan) or 'tool to separate rice' physically portrays the face of a Javanese woman like a full moon, which is round and full of light. Javanese woman whose face is like a full moon reflects the face of light in domestic life.

The basic ingredients of a tampah (winnowing pan) or 'tool to separate rice' are made of shiny yellow bamboo skin. Bamboo skin is woven with standard rules. These rules reflect the intelligence of the ancestors in the past. This intelligence covers the fields of health, ecosystems, and culture. The health sector is reflected that separating rice in a bamboo bin will easily clean rice grains without removing rice bran which has a source of vitamin B-6 and contains high fiber. Separating rice in a tampah (winnowing pan) will ensure the cleanliness of grains of rice that contain many benefits for human health. In the field of ecosystems, by utilizing bamboo as the basis for making tampah (winnowing pan), people will avoid the use of metals and will encourage Javanese people to preserve bamboo planting which is also suspected to have high levels of groundwater storage. In the cultural field, the tampah (winnowing pan) has a symbol as a religious lifeline, which always reminds oneself of the Almighty. The philosophical value lies in the Javanese swing movement in moving the tampah (winnowing pan), always to the left (circular to the left) seven times. This movement is analogous to the movement of Muslims in performing tawaf to the Kaaba with seven rounds to the left.

The uniqueness and function of the tampah (winnowing pan), apart from being a description of the Javanese woman's character who always maintains health for her family, maintain a balance with nature, is also a human being who always draws closer to the Almighty so that her household can be guaranteed of integrity and harmony. The philosophy of tampah (winnowing pan) can be likened to a Javanese woman whose face always shines for her family and always draws closer to the ruler of the universe so that her family lives in harmony.

\section{Conclusion}

The conclusion from this study is that the character of Javanese women adheres to traditional household appliances. The identity of the naming lexicon in household appliances is produced by considering three elements, namely religious elements, natural elements, and philosophical elements. The religious element adheres to the process of making equipment and using traditional household appliances. The natural element adheres to the basic ingredients of traditional household appliances. The philosophical element adheres to the identity of the lexicon of the traditional household equipment.

The identity of the lexicon contained in traditional household equipment is carried out by considering three semantic components, namely (1) the word/lexicon of traditional household equipment, (2) the concept of naming traditional household appliances that 
reflects Javanese culture, (3) references referred to by the equipment traditional. The three semantic components have a binding relationship between one component with another component.

\section{References}

1. S. Widada, A. Satriadi, and B. Rochaddi, "Kajian Potensi Air Tanah Berdasarkan Data Geolistrik Resistiviti Untuk Antisipasi Kekeringan Di Wilayah Pesisir Kangkung, Kabupaten Kendal, Privinsi Jawa Tengah,” J. Kelaut. Trop., (2017)

2. R. Hatu, "Perubahan Sosial Kultural Masyarakat Pedesaan (Suatu Tinjauan TeoritikEmpirik)," J. Inov., vol. 8, no. 4, pp. 1-11 (2011)

3. Sintia Dewi Wulanningrum, "Kajian Pola Tatanan Kehidupan di Kabuyutan Trusmi, Cirebon," J. Koridor, vol. 9, no. 2, pp. 322-328, (2018)

4. C. R. Margules and R. L. Pressey, "Systematic conservation planning," Nature. (2000)

5. M. Suryadi and R. Tiani, "Explaining the Natural Materials of Traditional Kitchen Appliances in the Javanese Coastal Communities Based on Internal Structure Formation of Lingual Units," in E3S Web of Conferences, (2019)

6. M. Suryadi, "The Performance Portrait of Javanese Women in Association with the Water Storage Appliances within the Traditional Society," (2019)

7. A. Rusdina, "Membumikan Etika Lingkungan Bagi Upaya Membudayakan Pengelolaan Lingkungan yang Bertanggung Jawab," Istek, (2015)

8. I. Y. Fernandez, "Kategori Dan Ekspresi Linguistik Dalam Bahasa Jawa Sebagai Cermin Kearifan Lokal Penuturnya: Kajian Etnolinguistik Pada Masyarakat Petani Dan Nelayan," Kaji. Linguist. dan Sastra, (2008)

9. R. M. Nur Sakinah, "Pandangan Orientalis terhadap Identitas dan Isu Politik Tokoh Perempuan dalam Putri Cina," Patanjala J. Penelit. Sej. dan Budaya, (2014)

10. I. Nurfitriati, "Rencana Tata Bangunan dan Lingkungan (Rtbl) dalam Menata Ruang Kota," Verit. Justitia, (2015)

11. J. A. Lucy, "Sapir-Whorf Hypothesis," in International Encyclopedia of the Social \& Behavioral Sciences: Second Edition, (2015)

12. C. K. Ogden, I. A. Richards, and J. Constable, The meaning of meaning: A study of the influence of language upon thought and of the science of symbolism. (2014) 